\title{
Purification and Characterization of Protein Phosphatase 2A from Petals of the Tulip Tulipa gesnerina
}

\author{
Md. Abul Kalam Azad ${ }^{1,2}$, Yoshihiro Sawa ${ }^{1}$, Takahiro Ishikawa ${ }^{1}$ and Hitoshi Shibata,* \\ ${ }^{1}$ Department of Life Science and Biotechnology, Shimane University, Matsue, Shimane 690-8504, Japan \\ ${ }^{2}$ Department of Biotechnology, Shah Jalal University of Science and Technology, Sylhet 3114, Bangladesh
}

Received 6 May 2006, Accepted 19 June 2006

The holoenzyme of protein phosphatase (PP) from tulip petals was purified by using hydrophobic interaction, anion exchange and microcystin affinity chromatography to analyze activity towards $p$-nitrophenyl phosphate ( $p$ NPP). The catalytic subunit of PP was released from its endogenous regulatory subunits by ethanol precipitation and further purified. Both preparations were characterized by immunological and biochemical approaches to be PP2A. On SDS-PAGE, the final purified holoenzyme preparation showed three protein bands estimated at 38 , 65 , and $75 \mathrm{kDa}$ while the free catalytic subunit preparation showed only the $38 \mathrm{kDa}$ protein. In both preparations, the $38 \mathrm{kDa}$ protein was identified immunologically as the catalytic subunit of PP2A by using a monoclonal antibody against the PP2A catalytic subunit. The final 623- and 748fold purified holoenzyme and the free catalytic preparations, respectively, exhibited high sensitivity to inhibition by 1 nM okadaic acid when activity was measured with $p$-NPP. The holoenzyme displayed higher stimulation in the presence of ammonium sulfate than the free catalytic subunit did by protamine, thereby suggesting different enzymatic behaviors.

Keywords: Holoenzyme and catalytic subunit, Microcystinaffinity, Okadaic acid, Protein phosphatase 2A, Tulip petal

\section{Introduction}

It is well recognized that reversible protein phosphorylation exerts a pivotal role as a major mechanism in the control of many cellular functions such as hormonal, pathogenic or environmental stimuli responses, cell cycle events, growth

\footnotetext{
*To whom correspondence should be addressed.

Tel: 81-0852-32-6585, Fax: 81-0852-32-6092

E-mail: shibata@life.shimane-u.ac.jp
}

factor responses, metabolic controls, and developmental processes (Janssens and Goris, 2001; Kerk et al., 2002). Proteins that are phosphorylated by different protein kinases are regulated via dephosphorylation by protein phosphatase (PPs) (Lechward et al., 2001). Although protein phosphatase are diverse in their structure and their evolution, they can be grouped simply by substrate specificities to phosphorylated Ser/Thr, or Tyr and dual specificity classes when the former group is encoded by the PPP and PPM gene families (Kerk et al., 2002; Luan, 2003). The PPP family comprises the classical groups PP1, PP2A, and PP2B (calcineurin) as well as a growing list of novel protein phosphatase including PP4, PP5, PP6 and PP7, whereas the $\mathrm{Mg}^{2+}$-dependent PP2C belongs to the PPM family (Sefton and Hunter, 1998; Stubbs et al., 2001; Luan, 2003). Many homologues of animal Ser/Thr phosphatase (PP1, PP2A, PP2C and PP5) have been detected in plants (Meek et al., 1999; Stubbs et al., 2001; Awotunde et al., 2003). The PP1 group is inhibited by the heat stable mammalian originated proteins, inhibitor-1 (I-1) and inhibitor2 (I-2), while the PP2 group is resistant to both inhibitors (Smith and Walker, 1996; Sefton and Hunter, 1998). Okadaic acid (OA) is a potent inhibitor for PP1 and PP2A, and to a lesser extent $\mathrm{PP} 2 \mathrm{~B}$, whereas $\mathrm{PP} 2 \mathrm{C}$ is resistant to OA (Takai and Mieskes, 1991; Sefton and Hunter, 1998; Messner et al., 2006). PP2Bs and PP2Cs require $\mathrm{Ca}^{2+}$ and $\mathrm{Mg}^{2+}$, respectively, for their activity whereas PP2As and PP1 have no divalent cation requirement (Sefton and Hunter, 1998). However, polycations such as protamine have been reported to stimulate only the PP2As (Cohen et al., 1988; Awotunde et al., 2000).

In general, PP2As exist as oligomeric complexes and consist of a catalytic subunit and one or more regulatory subunits named A and B (Awotunde et al., 2000; Janssens and Goris, 2001; Stubbs et al., 2001). These subunits play a significant role in the regulation of activity and in the specificity of the holoenzyme of different tissues and their cellular compartments by interacting within these subunits or other cellular proteins (Turowski et al., 1997; Meek et al., 1999; Janssens and Goris, 2001).

Previous studies showing the involvement of PP2As in 
controlling cellular functions, suggested the existence of several different complexes of the holoenzymes of PP2A in plants (Luan 2003). The homology-based molecular cloning approaches have been applied in identifying the catalytic subunit of PP2As' in Arabidopsis (Perez-Callejon et al., 1998), rice (Chang et al., 1999) and tobacco (Suh et al., 1998); and the regulatory A, B and B' subunits in Arabidopsis (Slabas et al., 1994; Corum et al., 1996; Haynes et al., 1999). These results suggest a much greater complexity of PP2A holoenzymes in plants than is found in mammalian cells. Biochemical approaches, however, are very limited to date in the study of plant PP2As. Moreover, there is no report for plants that compares the enzymatic behavior of PP2A holoenzyme and its free catalytic subunit. Our previous study demonstrated that the plasma membrane aquaporin (PMAQP) from tulip petals was phosphorylated by a membrane associated $\mathrm{Ca}^{2+}$-dependent protein kinase that regulated temperature-sensing for tulip petal opening at $20^{\circ} \mathrm{C}$ and that the dephosphorylation of phosphorylated PM-AQP was observed during petal closing at $5^{\circ} \mathrm{C}$ (Azad et al., 2004). PP is a key factor in cell signaling by reversible phosphorylation accomplishing the dephosphorylation of phosphorylated proteins. In this study, we demonstrate the purification of protein phosphatase as the holoenzyme and the free catalytic subunit from tulip petals in detail and characterize it as PP2A by using both biochemical and immunological approaches. The distinguishable enzymatic behaviors of the holoenzyme and the free catalytic subunit are discussed at length.

\section{Materials and Methods}

Sources of tulips and reagents. Tulips (Tulipa gesnerina $\mathrm{L}$. cv. Ile de France) were grown at a farm associated with the Shimane University. Two-day-old flowers were harvested and stored at $-80^{\circ} \mathrm{C}$. All chemicals were obtained from Wako Pure Chemical Industries unless noted otherwise. I-2, $p$-Nitrophenyl phosphate ( $p$-NPP), antiPP2A catalytic subunit (anti-PP2A/c) raised against mammalian PP2A catalytic subunit, and avidin-peroxidase conjugate were obtained from Sigma. Phenyl-Sepharose Cl 4B and DEAE-Toyopearl were purchased from Pharmacia and Tosoh respectively.

Assay of protein phosphatase activities. The $p$-NPP phosphatase activity was determined according to the method described by Takai and Mieskes (1991). The reaction mixture $(500 \mu \mathrm{L})$ containing 100 $\mathrm{mM}$ Tris-HCl, $\mathrm{pH}$ 8.0, $1 \mathrm{mM}$ DTT, $2 \mathrm{mM} p$-NPP and an appropriate amount of the enzyme in the presence or absence of $1 \mu \mathrm{M}$ OA was incubated at $25^{\circ} \mathrm{C}$ for $10 \mathrm{~min}$. The reaction was started with the addition of $p$-NPP and stopped by the addition of $1 \mathrm{~mL}$ of $200 \mathrm{mM}$ $\mathrm{NaOH}$. Following a brief centrifugation (if necessary) the supernatant was used to measure the $p$-nitrophenol at $405 \mathrm{~nm}$ against the 0 -min control. The activity was calculated using $\varepsilon=18.5 \mathrm{mM}^{-1} \mathrm{~cm}^{-1}$ for $p$ nitrophenol in alkaline solution. One unit of phosphatase activity was defined as the amount of enzyme producing $1 \mu \mathrm{mol}$ of $p$-nitrophenol per min at $25^{\circ} \mathrm{C}$. OA was dissolved and diluted as previously described (Takai and Mieskes, 1991).
Preparation of Microcystin-Sepharose. Microcystin-Sepharose (MC-Sepharose) was prepared with slight modifications to the method previously described (Moorhead et al., 1994). A mixture of $1.5 \mathrm{~mL}$ deionized water, $2.0 \mathrm{~mL}$ DMSO, $0.67 \mathrm{~mL} 5 \mathrm{M} \mathrm{NaOH}$ and $1.0 \mathrm{~mL}$ aminoethanethiol- $\mathrm{HCl}(1 \mathrm{~g} / \mathrm{mL})$ was prepared and purged with $\mathrm{N}_{2}$ gas. One $\mathrm{mL}(1 \mathrm{mg} / \mathrm{mL})$ of MC-LR, previously purged with $\mathrm{N}_{2}$ gas, was added to the formerly purged solution and incubated at $50^{\circ} \mathrm{C}$ for $30 \mathrm{~min}$ under $\mathrm{N}_{2}$ purging. After cooling of the solution, an equal volume of glacial acetic acid was added, then diluted 5-fold with $0.1 \%(\mathrm{v} / \mathrm{v})$ trifluoroacetic acid (TFA) and the $\mathrm{pH}$ reduced to 1.5 with $100 \%$ TFA, and applied to a $\mathrm{C}_{18}$-Sep-pak cartridge previously equilibrated with $0.1 \%$ TFA. After washing the cartridge with $0.1 \%$ TFA in $10 \%$ acetonitrile, the derivatized aminoethanethiol MC-LR was eluted with $0.1 \%$ TFA in $100 \%$ acetonitrile, evaporated by rotary vacuum evaporation and resuspended in $50 \mu \mathrm{L}$ methanol. MC-LR that was converted to the aminoethanethiol derivative by this method was found to be $95 \%$ (Moorhead et al., 1994).

To prepare the MC-thioethaneamino-Sepharose, HiTrap NHSactivated HP ( $1 \mathrm{~mL}$, Amersham Biosciences) was washed first with deionized water and then with $10 \mathrm{~mL}$ ice cold $1 \mathrm{mM} \mathrm{HCl}$. Immediately, $500 \mu \mathrm{L} 50 \mathrm{mM} \mathrm{NaHCO}_{3}$, pH 9.2 containing $50 \mu \mathrm{L}$ of derivatized MC-LR in methanol was injected and the end capped, then allowed to stand for $3 \mathrm{~h}$ at room temperature; the column was then washed and preserved according to the manufacturers guidelines.

Purification of the holoenzyme and the catalytic subunit from tulip petals. Five hundred grams of tulip petals were taken from $-80^{\circ} \mathrm{C}$ storage, crushed into small pieces, and placed in a homogenizer. Upon thaw completion, the petals were homogenized with 1 liter of homogenization buffer $(20 \mathrm{mM}$ Tris-HCl, $\mathrm{pH} 7.5$, containing $250 \mathrm{mM}$ sucrose, $2 \mathrm{mM}$ EGTA, $2 \mathrm{mM}$ EDTA, $0.1 \%$ (v/v) 2-mercaptoethanol (2-ME), $2 \mathrm{mM}$ benzamidine, $2 \mu \mathrm{g} / \mathrm{mL}$ leupeptine, $2 \mu \mathrm{g} / \mathrm{mL}$ pepstain, and $1 \mathrm{mM}$ PMSF). The homogenate was filtered through four layers of cheesecloth, and the $\mathrm{pH}$ adjusted to 7.5. The filtrate was centrifuged at $13,000 \times g$ for $15 \mathrm{~min}$. The supernatant was saturated with $70 \%\left(\mathrm{NH}_{4}\right)_{2} \mathrm{SO}_{4}$, and the precipitate dissolved in buffer A (20 mM Tris-HCl, pH 7.5, containing 0.1 mM EGTA, 0.1 mM EDTA, 0.1\% 2-ME, $0.1 \mathrm{mM}$ PMSF, $1 \mathrm{mM}$ benzamidine and $10 \%$ glycerol) plus $20 \%\left(\mathrm{NH}_{4}\right)_{2} \mathrm{SO}_{4}$ using a polytron PT-MR 3100 homogenizer (Kinematica AG, Switzerland). The solution was centrifuged at $13,000 \times g$ for $15 \mathrm{~min}$, and the supernatant was recentrifuged at $120,000 \times \mathrm{g}$ for $30 \mathrm{~min}$ at $4^{\circ} \mathrm{C}$ before loading onto a phenyl-Sepharose CL $4 \mathrm{~B}$ column $(2.8 \times 20 \mathrm{~cm})$ that was previously equilibrated with buffer A containing $20 \%\left(\mathrm{NH}_{4}\right)_{2} \mathrm{SO}_{4}$. After loading, the column was washed with at least $500 \mathrm{~mL}$ of buffer $\mathrm{A}$ containing $20 \%\left(\mathrm{NH}_{4}\right)_{2} \mathrm{SO}_{4}$. Proteins were eluted batch-wise using buffer A containing 10, 5 and $0 \%\left(\mathrm{NH}_{4}\right)_{2} \mathrm{SO}_{4}$, respectively. Fractions containing the OA-sensitive $p$-NPP phosphatase activity eluted with $5 \%\left(\mathrm{NH}_{4}\right)_{2} \mathrm{SO}_{4}$ were pooled, dialyzed against buffer $\mathrm{A}$ and loaded onto DEAE-Toyopearl $650(2 \times 20 \mathrm{~cm})$ equilibrated with buffer A containing $20 \%$ glycerol. The column was washed until the $\mathrm{A}_{280}$ reached the baseline, and the protein was eluted with a linear $0-400 \mathrm{mM} \mathrm{NaCl}$ gradient in buffer A containing $20 \%$ glycerol using Biologic LP (Bio-Rad) at a flow rate $1 \mathrm{~mL} / \mathrm{min}$. Fractions of $2 \mathrm{~mL}$ were collected, and the active fractions were pooled, dialyzed for $3 \mathrm{~h}$ in buffer $\mathrm{A}$ and applied to an $\mathrm{MC}$ Sepharose column equilibrated with buffer B (20 mM Tris-HCl, pH 
7.5, containing $5 \%$ glycerol (v/v), $0.1 \mathrm{mM}$ EGTA, 0.1\% 2-ME (v/v), $0.1 \mathrm{mM}$ PMSF, and $1 \mathrm{mM}$ benzamidine). Unbound proteins were washed through with $100 \mathrm{~mL}$ of buffer $\mathrm{C}$ (50 mM Triethanolamine$\mathrm{HCl}, \mathrm{pH} 7.5$, containing $0.1 \mathrm{mM}$ EGTA, $5 \%$ (v/v) glycerol, $0.1 \%$ $(\mathrm{v} / \mathrm{v})$ 2-ME, $1 \mathrm{mM}$ benzamidine, and $1 \mathrm{mM}$ PMSF) plus $0.5 \mathrm{M}$ $\mathrm{NaCl}$ and $1 \mathrm{mM} \mathrm{MnCl}$. One void volume of buffer $\mathrm{C}$ containing 3 $\mathrm{M}$ sodium isothiocynate and $1 \mathrm{mM} \mathrm{MnCl} \mathrm{M}_{2}$ was passed through the column and the flow stopped for $30 \mathrm{~min}$. The flow was restarted, and $1 \mathrm{~mL}$ fractions were collected. Active fractions were pooled, dialyzed in buffer $\mathrm{C}$ containing $50 \%$ (v/v) glycerol, and concentrated with Centricon 10 and stored at $-80^{\circ} \mathrm{C}$.

To purify the free catalytic subunit, the process used for the holoenzyme described above was applied with the following additional procedure. The extract prepared after $70 \%\left(\mathrm{NH}_{4}\right)_{2} \mathrm{SO}_{4}$ saturation was dialyzed for $6 \mathrm{~h}$ against buffer A. To dissociate the catalytic subunit from the endogenous regulatory subunits, an ethanol precipitation step was performed with 5 volumes of room temperature $95 \%$ ethanol as described by Stubbs et al. (2001) before undergoing phenyl-Sepharose CL 4B chromatography.

Immunodetection. Following SDS-PAGE, proteins in the $12.5 \%$ polyacrylamide gel were transferred to a PVDF membrane. The membrane was blocked with $0.5 \%$ BSA in PBS $(137 \mathrm{mM} \mathrm{NaCl}$, $2.7 \mathrm{mM} \mathrm{KCl}, 10 \mathrm{mM} \mathrm{Na}_{2} \mathrm{HPO}_{4}$ and $2 \mathrm{mM} \mathrm{KH}_{2} \mathrm{PO}_{4}$ ) for $1 \mathrm{~h}$ with gentle agitation and then incubated with the primary antibody (antiPP2A/c in PBS) for $3 \mathrm{~h}$. After washing, the membrane was incubated with the secondary antibody, an avidin-peroxidase conjugate in PBS, for $3 \mathrm{~h}$. The signal was detected using $2 \mathrm{mM}$ 4-methoxy-1naphthol (Aldrich Chemical Co. Inc.) and $3 \mathrm{M} \mathrm{H}_{2} \mathrm{O}_{2}$ as substrates.

\section{Results}

Purification of the PP2A holoenzyme and catalytic subunit from tulip petals. To purify the holoenzyme from tulip petals, phenyl-Sepharose CL 4B hydrophobic chromatography, DEAEToyopearl anion exchange chromatography, and MC-Sepharose affinity chromatography were used. Chromatography on DEAEToyopearl produced a major peak of $p$-NPP phosphatase activity that was undetectable in the presence of a $1 \mu \mathrm{M}$ OA which is sufficient for complete inhibition of the PP1 and PP2A activities (Awotunde et al., 2000; Stubbs et al., 2001). Activity was eluted with $180-220 \mathrm{mM} \mathrm{NaCl}$ as shown in Fig. 1. As the final step, this preparation was further purified by affinity chromatography on MC-Sepharose. Phosphatase was characterized as PP2A, as shown by figures 3 and 4. Table 1

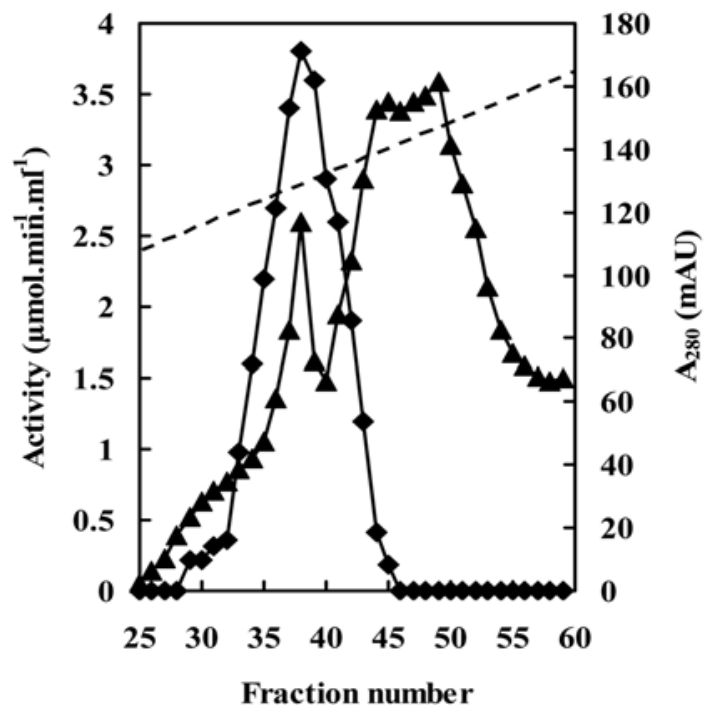

Fig. 1. DEAE-Toyopearl anion exchange chromatography of the holoenzyme. Fractions from phenyl-Sepharose CL-4B containing the $p$-NPP phosphatase activity inhibited by $1 \mu \mathrm{M}$ OA were pooled and loaded onto a DEAE-Toyopearl column. Proteins were eluted with a linear $0-400 \mathrm{mM} \mathrm{NaCl}$ gradient (dashed line). Fractions were assayed for $p$-NPP phosphatase activity $(\bullet)$, which was measurable in the absence of OA but disappeared in the presence of $1 \mu \mathrm{M}$ OA. The $A_{280}$ profile $(\boldsymbol{\Delta})$ is indicated.

summarizes the purification of the PP2A holoenzyme, resulting in a final 623-fold purified holoenzyme with a specific activity of $380 \mathrm{U} / \mathrm{mg}$ and a typical yield of $13 \%$. On SDS-PAGE, the purified holoenzyme yielded three protein bands of 75, 65 and $38 \mathrm{kDa}$ (Fig. 2A). Alternatively, the free catalytic subunit was purified by the same procedures plus an ethanol precipitation step before undergoing hydrophobic chromatography. Table 2 shows the purification profiles of the free catalytic subunit. After the final step, the 748-fold purified catalytic subunit had a specific activity of $449 \mathrm{U} / \mathrm{mg}$ with a yield of $11 \%$. SDS-PAGE (Fig. 2B) revealed the presence of only one protein of $38 \mathrm{kDa}$.

Identification and characterization of PP2A. To identify the catalytic subunit of the holoenzyme and the free catalytic preparations, immunodetection was performed using anti$\mathrm{PP} 2 \mathrm{~A} / \mathrm{c}$. This antibody clearly reacted with the $38 \mathrm{kDa}$ protein in both preparations as shown in Fig. 3, indicating that the 38

Table 1. Purification of PP2A holoenzyme from tulip petals*

\begin{tabular}{lccccc}
\hline \multicolumn{1}{c}{ Step } & $\begin{array}{c}\text { Protein } \\
(\mathrm{mg})\end{array}$ & $\begin{array}{c}\text { Total activity } \\
(\mathrm{U})\end{array}$ & $\begin{array}{c}\text { Specific activity } \\
(\mathrm{U} / \mathrm{mg})\end{array}$ & $\begin{array}{c}\text { Purification } \\
\text { fold }\end{array}$ & $\begin{array}{c}\text { Yield } \\
(\%)\end{array}$ \\
\hline $70 \%\left(\mathrm{NH}_{4}\right)_{2} \mathrm{SO}_{4}$ ppt. & 337 & 204 & 0.61 & 1 & 100 \\
Phenyl-Sepharose & 103 & 159 & 1.54 & 2.5 & 78 \\
DEAE-Toyopearl & 5.7 & 56 & 9.8 & 16.1 & 27 \\
MC-Sepharose & 0.071 & 27 & 380 & 623 & 13.2 \\
\hline
\end{tabular}

*The data are typical of the three preparations. 

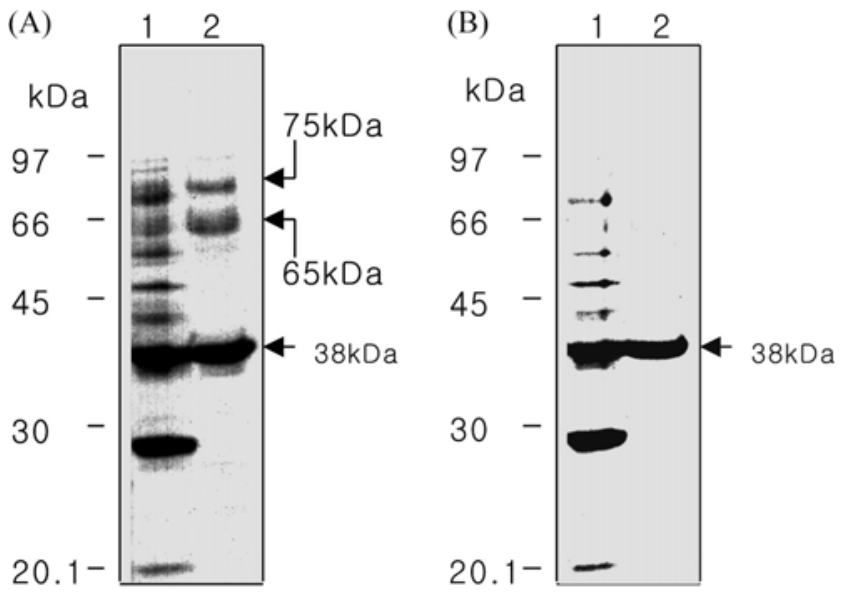

Fig. 2. SDS-PAGE of purified PP2A from tulip petals. After SDS-PAGE, the PP2A holoenzyme (A) and the catalytic subunit (B) were stained with Coomasie brilliant blue. Molecular masses of the standard proteins are shown in both panels (marked in the left side). Seven $\mu \mathrm{g}(\mathrm{A}$, lane 1$)$ and $6 \mu \mathrm{g}(\mathrm{B}$, lane 1$)$ of the DEAE-Toyopearl pool, and $3 \mu \mathrm{g}$ (A, lane 2) and $2.7 \mu \mathrm{g}(\mathrm{B}$, lane 2) of the MC-Sepharose pool were applied.

$\mathrm{kDa}$ protein was the PP2A catalytic subunit, and that both the 75 and $65 \mathrm{kDa}$ proteins might be regulatory subunits since they were co-purified with the catalytic subunit.

Both preparations were further characterized by OA, the specific inhibitor of PPs (Takai and Mieskes, 1991), and by protamine, a polycation that stimulates PP2A (Awotunde et al., 2000). Fig. 4A indicates that the $p$-NPP phosphatase activities of the holoenzyme, as well as the free catalytic subunit preparations, were inhibited almost completely by $1 \mathrm{nM}$ OA. The calculated $\mathrm{IC}_{50}$ values for the holoenzyme and for the catalytic preparations approximated $0.11 \mathrm{nM}$ and $0.09 \mathrm{nM}$, respectively. These values were comparable to those reported for other PP2As (Awotunde et al., 2000; Smith and Walker, 1996). PP1 is unaffected by $1 \mathrm{nM}$ OA because the $\mathrm{IC}_{50}$ of OA for PP1 ranges from 10-100 nM (Smith and Walker, 1996; Sefton and Hunter, 1998; Stubbs et al., 2001), suggesting that both preparations were free from PP1. Moreover, $p$-NPP phosphatase activities of the purified enzyme preparations were marginally inhibited ( $4 \pm 2 \%$ ) by $200 \mathrm{nM}$ of I-2 (data not shown), a concentration normally sufficient for complete inhibition of PP1 since the $\mathrm{IC}_{50}$ of the $\mathrm{I}-2$ for PP1 reportedly is

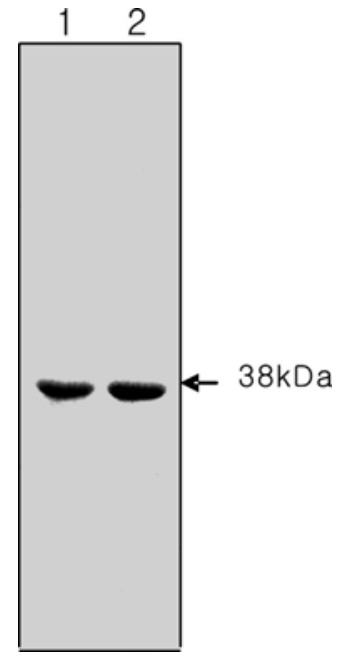

Fig. 3. Immunodetection of the PP $2 \mathrm{~A}$ catalytic subunit using anti-PP2A/c. A $3 \mu \mathrm{g}$ of the finally purified holoenzyme (lane 1) and the free catalytic subunit (lane 2) preparations were used for the immunoblot.

$0.65 \mathrm{nM}$ (Stubbs et al., 2001). Protamine has a pronounced stimulatory effect on the PP2As from both plant and animal sources, and in the absence of $\left(\mathrm{NH}_{4}\right)_{2} \mathrm{SO}_{4}$ the degree of stimulation is much lower (Cohen et al., 1988; Awotunde et al., 2000). As shown in Fig. 4B, $25 \mu \mathrm{g} / \mathrm{mL}$ protamine stimulated the $p$-NPP phosphatase activities of the holoenzyme and the free catalytic subunit by 5.5- and 4.0fold, respectively, in the presence of $16 \mathrm{mM}\left(\mathrm{NH}_{4}\right)_{2} \mathrm{SO}_{4}$. Insignificant stimulation by protamine was observed in both preparations in the absence of $\left(\mathrm{NH}_{4}\right)_{2} \mathrm{SO}_{4}$. The inhibitory effect exerted by sub-nanomolar concentrations of OA, the insensitivity to a high concentration of I-2, and the stimulatory effect of protamine further confirmed that the holoenzyme and the catalytic subunit preparations in this study were PP2A.

\section{Discussion}

To assay the protein phosphatase activity during the course of purification and for the characterization of PP from tulip petals, we used $p$-NPP as the substrate because the PP2As from plant and animal tissues exhibited higher activity with $p$ -

Table 2. Purification of free PP $2 \mathrm{~A} / \mathrm{c}$ from tulip petals*

\begin{tabular}{lccccc}
\hline \multicolumn{1}{c}{ Step } & $\begin{array}{c}\text { Protein } \\
(\mathrm{mg})\end{array}$ & $\begin{array}{c}\text { Total activity } \\
(\mathrm{U})\end{array}$ & $\begin{array}{c}\text { Specific activity } \\
(\mathrm{U} / \mathrm{mg})\end{array}$ & $\begin{array}{c}\text { Purification } \\
\text { fold }\end{array}$ & $\begin{array}{c}\text { Yield } \\
(\%)\end{array}$ \\
\hline $70 \%\left(\mathrm{NH}_{4}\right)_{2} \mathrm{SO}_{4}$ ppt. & 329 & 197 & 0.6 & 1 & 100 \\
EtOH precipitation & 81 & 136 & 1.7 & 2.8 & 69 \\
Phenyl-Sepharose & 52 & 110 & 2.1 & 3.5 & 56 \\
DEAE-Toyopearl & 3.1 & 47 & 15.2 & 25.3 & 24 \\
MC-Sepharose & 0.049 & 22 & 449 & 748 & 11 \\
\hline
\end{tabular}

*The data are representative of the three preparations. 

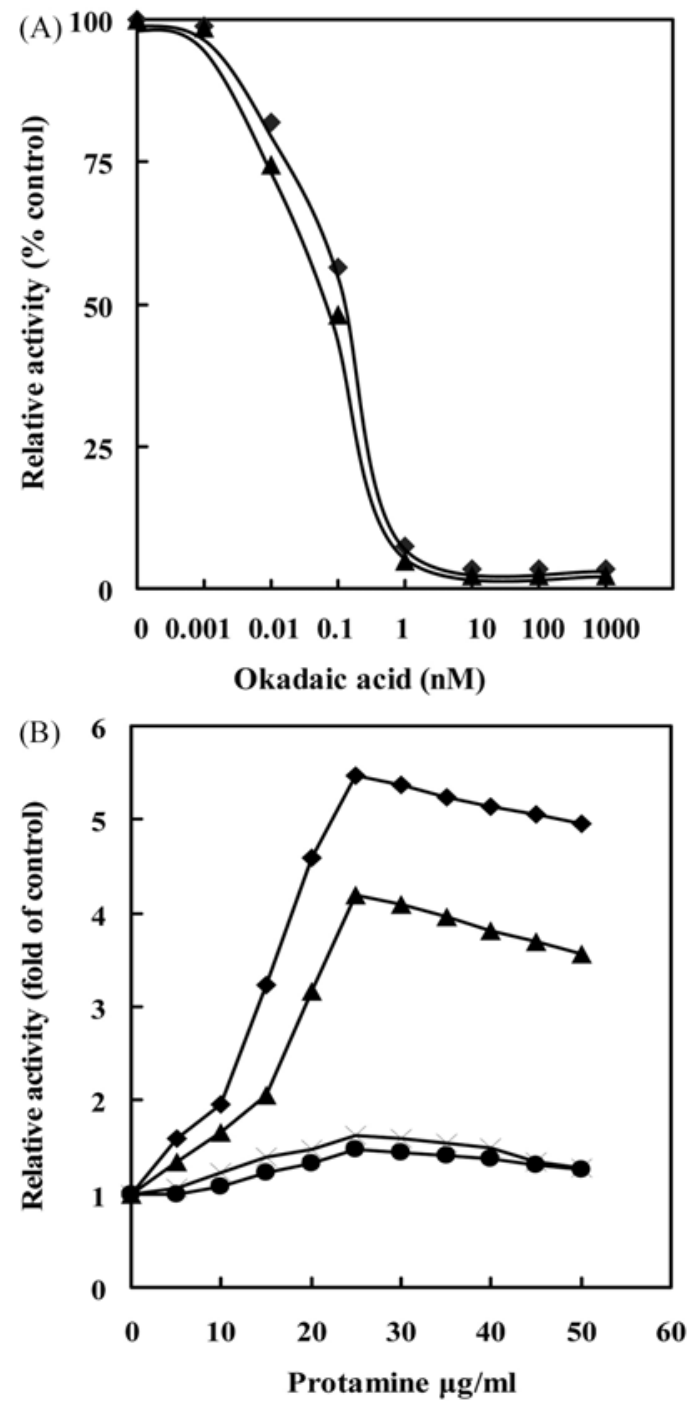

Fig. 4. Effect of OA and protamine on $p$-NPP phosphatase activities of purified enzyme preparations. (A) Activities of the holoenzyme $(\boldsymbol{\nabla})$ and the free catalytic subunit $(\boldsymbol{\Delta})$ were measured in the presence of several concentrations of $\mathrm{OA}$ in the reaction mixture at $25^{\circ} \mathrm{C}$ for $10 \mathrm{~min}$. (B) Activities of the holoenzyme in the presence $(\checkmark)$ or absence $(-)$ of $\left(\mathrm{NH}_{4}\right)_{2} \mathrm{SO}_{4}$ and of the free catalytic subunit in the presence $(\boldsymbol{\Delta})$ or absence $(\mathrm{X})$ of $\left(\mathrm{NH}_{4}\right)_{2} \mathrm{SO}_{4}$ were estimated with several concentrations of protamine. Data are typical of triplicate experiments.

NPP than phosphorylase $a$ (Takai and Mieskes, 1991; Awotunde et al., 2000). Moreover, the preparation of phosphorylase $a$, involving phosphorylase kinase, is expensive and requires facilities for the use of radioisotopes. This study, therefore, demonstrates that $p$-NPP may be used as a substrate for the biochemical study of plant PPs and excludes expensive materials and special facilities for using of radio isotope. The use of ethanol precipitation is usually limited to dissociate the catalytic subunit of animal PPs (Deguzman and Lee, 1988), however, Stubbs et al. (2001) were successful in detaching the catalytic subunit of Arabidopsis PP1 by this method. Protein precipitation is usually achieved with cold (normally from the $-20^{\circ} \mathrm{C}$ freezer) ethanol and the subsequent incubation maintained at least bellow $4^{\circ} \mathrm{C}$ (generally at $-20^{\circ} \mathrm{C}$ ). The successful dissociation of catalytic subunits, however, depends on performing the precipitation step at room temperature; this step reduces the enzyme to its catalytic subunit and removes a major portion of the inert protein (Deguzman and Lee, 1988). In this study, we detail the first report of PP2A catalytic subunit $(\mathrm{PP} 2 \mathrm{~A} / \mathrm{c})$ separation from a plant. The separation process successfully developed indicates that precipitation with high concentration of ethanol at room temperature may be used to free the catalytic subunit from the endogenous regulatory subunits of plant PPs in addition to the usual animal sources. The identification of the $38 \mathrm{kDa}$ protein as the PP2A/c (Fig. 3) in both preparations by specific immunoreactions with the monoclonal anti-PP $2 \mathrm{~A} / \mathrm{c}$ indicates close homologies within animal and tulip PP2A/c (Smith and Walker, 1996). The molecular masses of PP2A/c from Arabidopsis thaliana (Suh et al., 1998) and from maize seedlings (Awotunde et al., 2000) were consistent with the $38 \mathrm{kDa}$ of the tulip petal $\mathrm{PP} 2 \mathrm{~A} / \mathrm{c}$. At present the identities of 65 and $75 \mathrm{kDa}$ proteins in the holoenzyme preparation are not known, but the holoenzyme preparation has distinct properties when compared with the free $\mathrm{PP} 2 \mathrm{~A} / \mathrm{c}$ as will be discussed. MC is highly selective for the PP1 and PP2A holoenzymes as well as their catalytic subunits (Moorhead et al., 1994; Meek et al., 1999; Gonzalez et al., 2003). Since MC-Sepharose is used as the final step for purification of these PPs, and the $65 \mathrm{kDa}$ and $75 \mathrm{kDa}$ proteins have been co-purified with the catalytic subunit, the former one may be the constant regulatory subunit, and the latter a member of the variable B family of regulatory subunits. This speculation is based on the acceptance that the constant regulatory subunit is usually of $65 \mathrm{kDa}$ and the variable subunits range $54-130 \mathrm{kDa}$ (Luan, 2003). The relative abundance of these subunits, however, is low in comparison with that of the PP2A/c (Fig. 2A), which may reflect their tendency to dissociate from the catalytic subunit during purification, the susceptibility of regulatory subunits to proteolysis, a low concentration in the cells, the complexity of their multiple molecular forms or their different sensitivities to staining (Awotunde et al., 2000; Moorhead et al., 1994).

The $p$-NPP phosphatase activity of both preparations was inhibited by sub-nanomolar concentrations of OA (Fig. 4A) and was stimulated by protamine, but only in the presence of $\left(\mathrm{NH}_{4}\right)_{2} \mathrm{SO}_{4}$ (Fig. 4B). In addition to these properties, a lack of inhibition by I-2 and the reactivity with anti-PP2A/c led us to conclude that the purified PP from tulip petals was PP2A. The holoenzyme composition of PP2A provides many possibilities for the regulation of numerous cellular functions (Janssens and Goris, 2001). In the presence of different regulatory subunits, animal PP2As not only determine the substrate specificity in vitro but also the catalytic activity of PP2A towards the same substrate (Turowski et al., 1997; Janssens and Goris, 2001). There is so far, however, no report that contrasts the enzymatic behavior of PP2A as holoenzyme and 
free $\mathrm{PP} 2 \mathrm{~A} / \mathrm{c}$ from a plant. With this in mind, the $\mathrm{PP} 2 \mathrm{~A} / \mathrm{c}$ was dissociated from its endogenous regulatory subunits to enable comparison of biochemical responses to the same modulator. As shown in Fig. 4B, the holoenzyme was stimulated by protamine to a greater extent than the free $\mathrm{PP} 2 \mathrm{~A} / \mathrm{c}$, and repeated experimentation showed that the holoenzyme and the free PP2A/c have a somewhat different $\mathrm{IC}_{50}$ to OA (Fig. 4A). These results, therefore, suggest that the $65 \mathrm{kDa}$ and/or $75 \mathrm{kDa}$ subunits not only play a structural role as a modulator scaffold, but also allosterically modulate the enzymatic properties of the $\mathrm{PP} 2 \mathrm{~A} / \mathrm{c}$. To our knowledge, this appears to be the first report showing different enzymatic behaviors of the PP2A holoenzyme and free PP2A/c from a plant in response to the same modulator.

\section{References}

Awotunde, O. S., Lechward, K., Krajewska, K., Zomierowicz, S. and Muszynska, G. (2003) Interaction of maize (Zea mays) protein phosphatase 2A with tubulin. Acta Biochim. Polon. 50, 131-138.

Awotunde, O. S., Sugajska, E., Zolnierowicz, S. and Muszynska, G. (2000) Characterization of two protein phosphatase 2A holoenzymes from maize seedlings. Biochim. Biophys. Acta 1480, 65-76.

Azad, A. K., Sawa, Y., Ishikawa, T. and Shibata, H. (2004) Phosphorylation of plasma membrane aquaporin regulates temperature-dependent opening of tulip petals. Plant Cell Physiol. 45, 608-617.

Chang, M., Wang, B., Chen, X. and Wu, R. (1999) Molecular characterization of catalytic-subunit cDNA sequences encoding protein phosphatase 1 and $2 \mathrm{~A}$ and study of their roles in the gibberellin-dependent Osamy-c expression in rice. Plant Mol. Biol. 39, 105-115.

Cohen, P., Alemany, S., Hemmings, B. A., Resink, T. J., Stralfors, P. and Tung, H. Y. L. (1988) Protein phosphatase-1 and protein phosphatase-2A from rabbit skeletal muscle. Methods Enzymol. 159, 390-408.

Corum, J. W., Hartung, A. J., Stamey, R. T. and Rundle, S. J. (1996) Characterization of DNA sequences encoding a novel isoform of the $55 \mathrm{kDa} \mathrm{B}$ regulatory subunit of the type $2 \mathrm{~A}$ protein serine/threonine phosphatase of Arabidopsis thaliana. Plant Mol. Biol. 31, 419-427.

Deguzman, A. and Lee, E. Y. C. (1988) Preparation of lowmolecular-weight forms of rabbit muscle protein phosphatase. Methods Enzymol. 159, 356-368.

Gonzalez, J., Cornejo, A., Santos, M. R. M., Cordero, E. M., Gutierrez, B., Porcile, P., Mortara, R. A., Sagua, Hernan., Silveira, J. F. D. and Araya, J. E. (2003) A novel protein phosphatase 2A ( $\mathrm{PP} 2 \mathrm{~A})$ is involved in the transformation of human protozoan parasite Trypanosoma cruzi. Biochem. J. 374, 647-656.

Haynes, J. G., Hartung, A. J., Hendershot, J. D., Passingham, R. S. and Rundle, S. J. (1999) Molecular characterization of the B' regulatory subunit gene family of Arabidopsis protein phosphatase 2A. Eur. J. Biochem. 260, 127-136.

Janssens, V. and Goris, J. (2001) Protein phosphatase 2A: a highly regulated family of serine/threonine phosphatases implicated in cell and signaling. Biochem. J. 353, 417-439.

Kerk, D., Bulgrien, J., Smith, D. W, Barsam, B., Veretnik, S. and Gribskov, M. (2002) The complement of protein phosphatase catalytic subunits encoded in the genome of Arabidopsis. Plant Physiol. 129, 909-925.

Lechward, K., Awotunde, O. S., Swiatek, W. and Muszynska, G. (2001) Protein phosphatase 2A: Variety of forms and diversity of functions. Acta Biochim. Polon. 48, 921-933.

Luan, S. (2003) Protein phosphatases in plants. Annu. Rev. Plant Biol. 54, 63-92.

Meek, S., Morrice, N. and Mackintosh, C. (1999) Mycrocystin affinity purification of plant protein phosphatases: PP1C, PP5 and a regulatory A-subunit of PP2A. FEBS Lett. 457, 494-498.

Messner, D. J., Romeo, C., Boynton, A. and Rossie, S. (2006) Inhibitors of PP2A, but not PP5, mediates p53 activation by low level of okadaic acid in rat liver epithelial cells. J. Cell Biochem. Published Online: 5 Apr 2006.

Moorhead, G., Mackintosh, R. W., Morrice, N., Gallagher, T. and Mackintosh, C. (1994) Purification of type 1 protein (serine/ threonine) phosphatases by microcystin-Sepharose affinity chromatography. FEBS Lett. 356, 46-50.

Perez-Callejon, E., Casamayor, A., Pujol, G., Camps, M. Ferrer, A. and Arino, J. (1998) Molecular cloning and characterisation of two phosphatase catalytic subunit genes from Arabidopsis thaliana. Gene 209, 105-112.

Sefton, B. M. and Hunter, T. (1998) Protein phosphorylation; in Classification of Protein-Ser/Thr Phosphatases: Identification and Quantification in Cell Extracts. Cohen, P. (ed.), pp. 85-94, Academic press, San Diego, USA.

Slabas, A. R., Fordham-Skelton, A. P., Fletcher, D., MartinezRivas, J. M., Swinhoe, R., Croy, R. R. D. and Evans, L. M. (1994) Characterisation of cDNA and genomic clones encoding homologues of the $65 \mathrm{kDa}$ regulatory subunit of protein phosphatase 2A in Arabidopsis thaliana. Plant Mol. Biol. 26, 1125-1238.

Smith, R. D. and Walker, J. C. (1996) Plant protein phosphatases. Annu. Rev. Plant Physiol. Plant Mol. Biol. 47, 101-125.

Stubbs, M. D., Tran, H. T., Atwell, A. J., Smith, C. S, Olson, D. and Moorhead, G. B. G. (2001) Purification and properties of Arabidopsis thaliana type 1 protein phosphatase (PP1). Biochim. Bbiophys. Acta 1550, 52-63.

Suh, M. C., Cho, H. S., Kim, Y. S., Liu, J. R. and Lee, H. S. (1998) Multiple genes encoding serine/threonine protein phosphatases and their differential expression in Nicotiana tabacum. Plant Mol. Biol. 36, 315-322.

Takai, A. and Mieskes, G. (1991) Inhibitory effect of okadaic acid on the $p$-nitrophenyl phosphate phosphatase activity of protein phosphatases. Biochem. J. 274, 233-239.

Turowski, P., Favre, B., Campbell, K. S., lamb, N. J. C. and Hemmings, B. A. (1997) Modulation of the enzymatic properties of protein phosphatase $2 \mathrm{~A}$ catalytic subunit by the recombinant 65-kDa regulatory subunit PR65 $\alpha$. Eur. J. Biochem. 248, 200208. 